\title{
Detecção molecular da reativação simultânea de VZV e HSV em paciente com história clínica de roseola infantum
}

\author{
Molecular detection of simultaneous reactivation of VZV and HSV in a patient with a clinical history of \\ roseola infantum
}

\author{
André Soares Rebello ${ }^{1}$ \\ Maria da Glória da Costa Carvalho ${ }^{2}$ \\ Maria Christina Soares Rebello ${ }^{3}$ \\ Juliana Fischer ${ }^{4}$ \\ Paulo Costa Carvalho ${ }^{5}$ \\ José Francisco de Oliveira Carvalho ${ }^{6}$
}

\begin{tabular}{l|l}
\multicolumn{1}{c|}{ unitermos } & res Um \\
VZV & $\begin{array}{l}\text { Paciente masculino de } 29 \text { anos, portador de um quadro febril acompanhado de exantema generalizado, } \\
\text { com suspeita de roseola infantum, apresentou desconforto e hiperemia do olho direito, além de lesões }\end{array}$ \\
HSV & $\begin{array}{l}\text { labiais vesiculares. Através da técnica da PCR diagnosticou-se que a lesão labial fora provocada pelo vírus } \\
\text { do herpes simples e a lesão ocular produzida pelo vírus da varicela-zoster. }\end{array}$ \\
Roseola infantum &
\end{tabular}

Diagnóstico molecular

abstract

A feverish 29-year-old man, with generalized exantema and suspicion of roseola infantum, presented discomfort and hiperemia on the right eye and labial vesicular injuries. Diagnosis through the PCR technique showed that the labial and ocular injuries were produced by herpes simples and varicela-zoster

virus respectively.

key words

vZv

HSV

Roseola infantum

Molecular diagnostic

\section{Introdução}

Vários membros da família Herpesviridae são patógenos importantes para o homem. Após a infecção primária, muitas vezes assintomática, ocorre o estabelecimento da latência, geralmente nos neurônios sensitivos. Entre os vírus desta família salientaremos o vírus do herpes simples dos tipos 1 e 2 (HSV 1/2), o vírus da varicela-zoster (VZV) e o herpesvírus humano 6 (HHV-6).

O herpesvírus humano 6, cuja infecção primária geralmente ocorre na infância, é o agente etiológico da roseola infantum. Como todo vírus neurotrópico, pode levar a convulsões febris e encefalites (1). O vírus do herpes simples (HSV), como é sabido, provoca uma série de manifestações clínicas, estando a orofaríngea entre as mais comuns. Na infecção primária observamos febre, faringite, lesões vesiculares e ulcerativas, entre outros sinais e sintomas. Quando ocorre a reci- diva, a doença se manifesta por vesículas, geralmente na borda dos lábios. O HSV é também agente causador de infecções oculares tanto na primoinfecção quanto nos casos de recidiva (3). O vírus varicela-zoster (VZV) é o agente etiológico da varicela e do herpeszoster. O herpes-zoster ocorre geralmente em adultos, como resultado da reativação de infecção latente, caracterizando-se por inflamação aguda dos nervos e dos gânglios sensoriais, induzindo à formação de vesículas (6).

A reação em cadeia da polimerase (PCR) é uma técnica de altas sensibilidade e especificidade, que permite a detecção de quantidades mínimas de DNA ou RNA. A PCR vem sendo utilizada como auxiliar do diagnóstico clínico, terapia, classificação e estudos epidemiológicos de doenças. Esta técnica permite um resultado geralmente mais rápido que os métodos tra-
1. Acadêmico de Medicina da Universidade Estácio de Sá; estudante de Iniciação Cientifica do Laboratório de Controle da Expressão Cênica do Instituto de Biofísica Carlos Chagas Filho (BCCF), Centro de Ciências da Saúde da Universidade Federal do Rio de Janeiro (CCS/UFR)).

2. Médica; doutora em

Ciências; professora

universitária da Universidade

Federal do Rio de Janeiro (UFR); chefe do Laboratório de Controle da Expressão Cênica do Instituto de Biofísica CCS/UFR).

3. Médica; doutora em Ciências; consultora científica do Laboratório Cênesis - Diagnósticos em Biologia Molecular.

4. Engenheira química com aperfeiçoamento em Biologia Molecular no Laboratório Cênesis Diagnósticos em Biologia Molecular. 5. Engenheiro com aperfeiçoamento em Biologia Molecular no Laboratório Cênesis - Diagnósticos em Biologia Molecular.

6. Médico; doutor em Ciências; diretor cientifico do Laboratório Cênesis - Diagnósticos em Biologia Molecular. 
dicionais. Outra vantagem da PCR é que ácidos nucléicos podem ser detectados em quase todas as secreções corporais, fluidos e tecidos. Atualmente, o diagnóstico das doenças infecciosas, particularmente as viroses, sofreu um avanço considerável após a implantação das técnicas moleculares, especialmente a PCR (10).

\section{Relato do caso}

MDFM, 29 anos, branco, farmacêutico, residente em Nova Iguaçu, Rio de Janeiro, natural do Rio de Janeiro. Queixa principal: manchas pelo corpo.

História da doença atual: o paciente relatou que no dia 17 de setembro de 2002 teve contato com uma criança no início de um quadro diagnosticado posteriormente, como roseola infantum. No dia seguinte iniciou quadro de astenia, prostração, mialgia e febre de $39^{\circ} \mathrm{C}$, evoluindo, após um dia, para exantemas maculopapulares indolores com distribuição pelo tronco e pelos membros, principalmente na coxa direita, onde coalesciam-se formando uma mancha pruriginosa; surgiram, também, pequenas vesículas na borda dos lábios e na ponta do nariz. O paciente relatou desconforto ocular e hiperemia da conjuntiva apenas do olho direito. Após o surgimento das vesículas, o paciente iniciou o uso de aciclovir tópico, pois já sabia ser portador crônico de herpes. Dois dias após o surgimento das lesões dermatológicas foram colhidas amostras de lágrima (olho direito) e saliva (região labial) para análise pela técnica da reação em cadeia.

\section{Objetivo}

O objetivo deste trabalho foi correlacionar o quadro clínico do paciente com a presença dos vírus herpes simples (HSV), herpesvírus humano tipo 6 e varicela-zoster $(V Z V)$, testando a eficácia dos métodos moleculares de diagnóstico.

\section{Material e métodos}

\section{Coleta}

Coletou-se swab de células provenientes da mucosa oral, na região da lesão, na borda dos lábios e da secreção lacrimal, do olho direito. As respectivas amostras foram identificadas e transportadas para o laboratório em temperatura ambiente.

\section{Extração do DNA}

O DNA foi extraído com DNAzol (Reagent, Gibco BRL, Life Technologies), conforme método descrito pelo fabricante. Resumidamente, os swabs foram imersos em tubo Eppendorf contendo $1 \mathrm{ml}$ de DNAzol e incubados à temperatura ambiente por cinco minutos; após a incubação, os swabs foram retirados, e, em seguida, foram adicionados $500 \mathrm{ul}$ de etanol; o material foi homogeneizado por inversão dos tubos e, posteriormente, centrifugado a $6.000 \mathrm{rpm}$ durante cinco minutos. Após a centrifugação, o precipitado foi lavado com etanol a $75 \%$ duas vezes. Após seco, o DNA foi suspenso em $20 \mu l$ de água.

\section{Reação em cadeia pela polimerase (PCR)}

O volume final da reação foi de 12,5 ul, contendo, em cada tubo, DNA teste $(1 \mu \mathrm{l})$ em presença de $1 \mu \mathrm{M}$ de cada par de primers para HSV, VZV e HHV-6, respectivamente $(2,7,9)$. A todos os tubos foi adicionado $0,2 \mathrm{mM}$ de cada nucleotídeo: dATP, dGTP, dCTP e dTTP; 2,5U de Taq DNA polimerase; tampão Tris- $\mathrm{HCl}(\mathrm{pH} 7,5)$ $10 \mathrm{mM}, \mathrm{KCl}$ a $50 \mathrm{mM}$ e $\mathrm{MgCl}_{2}$ a $1,5 \mathrm{mM}$. Como controle positivo da reação foram utilizados DNAs extraídos de células de pacientes reconhecidamente infectados, e como controle negativo não foi adicionado DNA à mistura de reação.

Na PCR foi realizada a seguinte ciclagem: desnaturação inicial a $94^{\circ} \mathrm{C}$ por $3 \mathrm{~min}$; desnaturação a $94^{\circ} \mathrm{C}$ por $40 \mathrm{~s}$; anelamento a $57^{\circ} \mathrm{C}$ por $40 \mathrm{~s}, 30$ ciclos; extensão a $72^{\circ} \mathrm{C}$ por $2 \mathrm{~min}$; extensão final a $72^{\circ} \mathrm{C}$ por $7 \mathrm{~min}$.

Os fragmentos resultantes da amplificação dos genes HSV, HHV-6 e VZV foram analisados em gel de poliacrilamida a $8 \%$ e corados pela prata.

\section{Resultado}

A análise do produto de amplificação de ambas as amostras, através do gel de poliacrilamida, é mostrada na Figura. A amostra correspondente à secreção lacrimal é positiva para o DNA do vírus da varicela-zoster (linha $A$, coluna 4), não tendo sido encontradas evidências para o DNA de HSV (linha C, coluna 4). Foi detectada a presença de DNA de HSV na amostra recolhida da lesão do lábio do paciente (linha C, coluna 3). Não foi detectado o DNA correspondente ao HHV-6 em nenhuma das amostras coletadas, como mostrado na linha B, colunas 3 e 4 . 


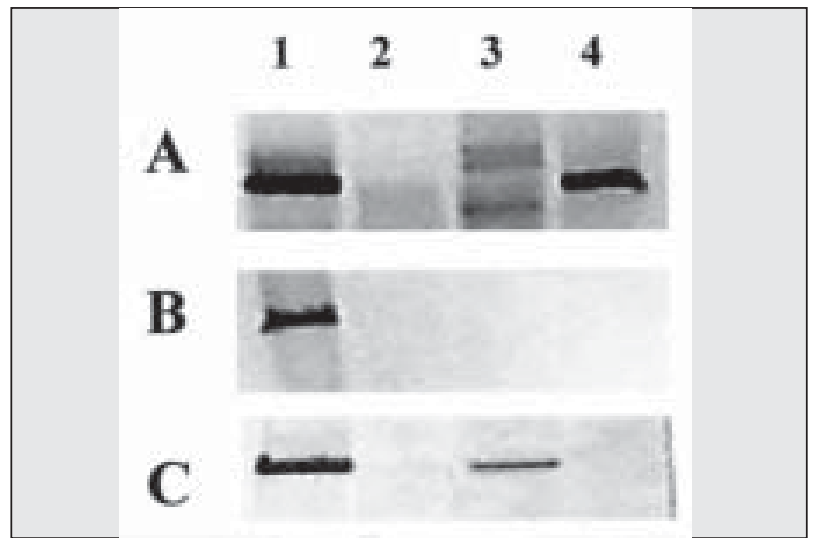

Figura - Amplificação por PCR dos vírus VZV (A), HHV-6 (B) e HSV (C). Visualização em gel de poliacrilamida a 8\% e coloração pela prata. Coluna 1: controle positivo; coluna 2: controle negativo; coluna 3: DNA extraído da região labial; coluna 4: DNA extraído da lágrima

\section{Discussão}

Geralmente o diagnóstico das lesões produzidas tanto por herpes-zoster quanto por herpes simples é feito clinicamente, sem maiores dificuldades. A experiência, entretanto, mostra que $20 \%$ das amostras com suspeita clínica de VZV enviadas ao laboratório para confirmação de diagnóstico por cultura revelam, na realidade, a presença do vírus do herpes simples como agente etiológico. Por outro lado, sabe-se que culturas, tanto para o VZV quanto para o HSV, são positivas em $80 \%$ dos casos somente quando as amostras são retiradas de lesões ativas; quando a vesícula está seca, a cultura apresenta positividade em apenas $20 \%$ dos casos. Mesmo a técnica de imunofluorescência direta, usando anticorpos específicos (que é mais sensível que a cultura) pode apresentar resultado negativo ou indeterminado. Nestas situações, a técnica da PCR mostra especificidade e sensibilidade superiores às técnicas tradicionais, sendo portanto o método diagnóstico de escolha $(4,5)$.

Estudos recentes mostram que o vírus HHV.6 pode entrar em latência no nervo facial, co-infectando este nervo junto com o VZV e provocando lesões oculares (8). A análise por PCR da lágrima destes pacientes mostra a presença simultânea de HHV-6 e VZV.

Nossos resultados mostram que:

- o paciente que, por sua história prévia, parecia ter uma conjuntivite e lesão labial por herpes simples, na realidade desenvolvera uma reativação do vírus do herpes simples na região labial; a lesão ocular, entretanto, era causada por reativação do vírus da varicela-zoster;

- embora o mesmo paciente tivesse aparentemente contraído infecção primária por HHV-6, desenvolvendo um quadro de roseola infantum, não foi possível detectar a presença deste vírus (HHV-6) na lágrima do paciente, aparentemente demonstrando que a infecção ocular foi devida exclusivamente ao VZV, e as lesões labiais, ao HSV. Não podemos, entretanto, excluir completamente a participação do HHV-6 no quadro do paciente, pois a quantidade deste vírus poderia estar abaixo da sensibilidade do método.

\section{Referências}

1. Braun, D.K.; D ominguez, G. \& Pellet, P.A . H uman herpesvirus 6. Clin. Microbiol. Rev., 10: 521-67, 1997.

2. Cao, M. et. al. Herpes simplex tipo 1-2, pol region (HSV). J. Invest. Dermatol., 92:391-2, 1989.

3. Caumes, E. N on-genital herpes simplex virus infections in adults. Clinical aspects, accuracy of clinical signs and evolution. Ann. Dermatol.Venereol.,129: 597-602, 2002.

4. D lugosch, D. et al. Diagnosis of acute and latent varicela-zo ster virus infections using the polymerase chain reaction.J.M ed. Virol., 35: 136-41, 1991.

5. Kido, S. et al. D etection of varicela-zoster (VZV) D N A in clinical samples from patients with VZV by polymerase chain reaction. J. Clin. M icrobiol., 29: 76-9, 1991.
6. Kleinschmidt-D eMasters, B. K. \& Gilden, D. H.Varicela-zoster virus infections of the nervous system: clinical and pathologic correlates. Arch. Pathol. Lab. M ed.,125:770-80, 2001.

7.MacKenzie,J.et al. Screening for herpesvirus genomes in common acute lymphoblastic leukemia. Leukemia, 15:415-21,2001.

8. Pitkãranta, A. et al. D etection of human herpesvirus 6 and varicela-zoster in tear fluid of patients with Bell's palsy by PCR. J. Clin. M icrobiol., 38: 2753-5, 2000.

9.Priya, K. et.al. A pplication of rapid aetiological diagnostic methods on intraocular specimens in viral retino-choroiditis. (www.jimm.org) Indian Journal of Medical Microbiology, 19(1), 2001.

10. Storch, G A. D iagnostic virology. Clin. Infect. Dis., 31: 739-51, 2000. 